\title{
モードスイッチにおける言語構造の切り替え 〜バイリンガル聴児Kのケーススタディーを通して〜
}

\author{
平 英司 \\ 関西学院大学 \\ taira82@gmail.com
}

\section{1. はじめに : 本論文の概要}

本論文では、日本語と日本手話の 2 言語環境に育つバイリンガル聴児 $\mathrm{K}(2007.10$ 生まれ女児）の言語使用を対象としたケーススタディーを行う。Kはろう児を兄 （2002.8生まれ）にもち、聞こえる（聴覚に障害のない）両親は日本手話を家庭のも う一つの言語とし、ろう児を日本手話で養育している。本研究では、手指と音声の 同時併用であるシムコムモードから音声を伴わない手指のみのモード（手指モード） への切り替え（モードスイッチ）に焦点を当てる。具体的には、モードスイッチの際 にKの手指表現に注目し、日本語の言語の仕組み（以下、本稿では「言語構造」と 呼ぶ）をもつ「手指日本語」から「日本手話」への切り替えをみていくものである。 結果、Kはシムコムモードの場合には、その手指表現は日本語の言語構造を有する 反面、音声を伴わない手指モードでは日本手話の言語構造を有する傾向にあること が明らかになった。このことから、Kはモードスイッチの際に言語構造の切り替え (コードスイッチ) を行っていることが示唆される ${ }^{1}$ 。

本論文では、2 節で研究の背景として、日本手話と日本語のバイリンガル家庭とバ イリンガル聴児の出現の背景と、バイリンガル聴児の言語使用の特徵であるモードス イッチについて述べる。その後、3 節で本研究のリサーチクエスチョンを述べ、4節で 研究対象となるバイリンガル聴児について言及する。5 節では、分析 1 として K の手 指モードに扔ける言語構造を確認し、6 節で分析 2 としてモードスイッチに扔ける言 語構造の切り替えを分析する。そして、7節で2つの分析結果を通しての結論を述べる。

\section{2. 研究の背景}

本研究は、近年出現し始めた日本手話と日本語のバイリンガル家庭を対象とした ものである。このような家庭を対象とした文献は養育事例が中心であり、家庭内の 
言語使用の状況等を研究対象としたものはほとんど見られない。そのため、本節で は日本手話と日本語のバイリンガル家庭を対象とした萌芽的な研究の立場から、ま ず日本手話と日本語のバイリンガル家庭の出現の背景について述べた後、バイリン ガル聴児とその特徵について論じることとする。

\section{1. 日本手話と日本語のバイリンガル家庭の出現}

日本では、ろう学校（聴覚特別支援学校）において教師が手話の使用を禁止し口 話で授業を行う口話法が長年用いられてきた。ヨーロッパで広まっていた口話法が 日本でも本格的に用いられるようになったのは、1920 年代のことである。1920 年に はヨーロッパでの口話法の影響のもと、日本聾話学校が設立され、以降それまで手 話を用いて教育を行っていた全国のろう学校は次々と手話を禁止するようになる。さ らに、1933 年には全国盲唖学校長会議で鳩山文部大臣が口話を奨励する訓示を出し、 手話はろう学校から排除されていった（米川 2002）。そのような中、1990年代にな ると手話の教育的位置づけが検討されるようになる。1991 年世界ろう者会議東京大 会では「バイリンガル・バイカルチャー教育」がアピールされ、1993 年には文部省 による「聴覚障害児のコミュニケーション手段に関する報告書」に手話についての 記載が盛り达まれた（都築 1997）。アンケート調査を実施し、70 校あまりのろう学 校から回答を得た我妻（2008）によると、2002 年の段階でろう学校の幼稚部、小学 部、中学部の $70 \%$ 以上で、手話での教育が導入されている。しかし、我妻（2008） の調査では、手話の種類や使用頻度までは調査対象とはしていない。千葉県聴覚障 害者協会（2011）は、教員の手話力についてろう学校にアンケート調査を行い、全 国のろう学校 93 校中 70 校から回答を得た。結果、全教職員 3936 名のうち手話がで きる教職員は約 55\%（2168 名）であった。さらに、手話ができるとした 2168 名のう ち約 $91 \%$ にたる 1969 名は日常会話程度の手話力であることが明らかとなった。ま た現在、教員の手話の能力を考慮したろう学校への配属や新しくろう学校に赴任し た教員に対する手話学習の義務化、研修制度などの公的施策はない。このように現 在でこそ手話活用を容認するろう学校も増えてはきたが、使用の実態は依然、十分 であるとは言い難い。

では、ろう児のいる家庭の場合はどうであろうか。ろう児をもつ親の多くは、ろう 児が生まれるまで、ろう者との交流や手話に触れることはない。こういった背景に基 づき、ろう学校には就学前のろう児をもつ親のために早期教育相談が設けられてい る。その結果、ろう児の専門家であるろう学校の方針が家庭の養育方針に大きな影 響を与えると考えられる。口話法の影響のもと、ろう学校の方針に追従する形で家 庭においても手話の使用が積極的に推奨されることはなかった。実際、ろう学校の 一部では小学校低学年まで、親が授業の様子を観察し、口話訓練を家庭でも実践す る母親法が推奨されてきた(中村 2003, 加藤 2007)。ろう児をもつ家庭にインタビュー 


\section{モードスイッチにおける言語構造の切り替え}

調査を行った加藤（2007）は、母親法が生み出す関係について「「母」と「娘」とい うよりも「言語治療士」と「患者」の関係 (P51)」と指摘している。

近年、このような動きに対し日本手話での教育の必要性を訴える動きも生じてい る。2002 年「ろう児の人権救済申立」がろう児とその親たち 107 名によってなさ れた（全国乃う児をもつ親の会 2004）。聞こえないろう児にとって日本手話こそが、 100\%理解できる言語であると認識し、日本手話での教育を受ける選択権を求めたの である。また、2008 年には、NPO 法人バイリンガル・バイカルチュラルろう教育セ ンターが私立のろう学校である明晴学園を東京都に設立した。明晴学園では、日本 手話を教育言語と位置付け教育を行っている。明晴学園にろう児を通わせている聞 こえる親たちは、日本手話を学び家庭でも手話での養育を行っている。このように、 ここ数年、関東を中心に日本手話と日本語のバイリンガル家庭は出現し始めた。

\section{2. バイリンガル聴児とモードスイッチ}

2. 1. でみてきたように、日本手話と日本語のバイリンガル家庭はここ数年、出現し 始めた新しいタイプの言語環境を有するバイリンガル家庭である。日本手話と日本 語のバイリンガル家庭に、ろう児の兄弟姉妹にあたる聴児がいる場合、家庭での言 語環境等により 2 つ言語能力の差異は見られたとしても、日常的に 2 つの言語に ふれ、日本語と日本手話とのバイリンガル児となる ${ }^{2}$ 。本稿では、このようなバイリ ンガル環境に育つ子ども達をバイリンガル聴児と呼ぶ。

バイリンガル聴児は音声での発話による日本語と手指（身体）での発話による日 本手話とを日常的に使用するバイモーダルでもある。音声と手指という2つの異なる 表現媒体 (モダリティー) を用いるバイリンガル聴児は(1)手指のみを用いるモード (手 指モード）や(2)音声のみを用いるモード（音声モード）に加え、(3)音声と手指との同 時併用であるシムコムモードという 3つのモードを有している。（Lucas\&Valli 1992, Emmorey 2005, 平 2008)。このことは、音声モードのみを有する音声言語同士バイ リンガル児とは異なる特徴と言える。

そして、手話と音声とのバイリンガル・バイモーダル話者の場合、一つの談話内 でも、モードが切り替えられ複数のモードが出現する場合がある。本稿では、この 現象を「モードスイッチ」と呼ぶ。

\section{3. リサーチクエスチョン}

\section{1. バイリンガル聴児の言語使用に対する懸念}

2. 1. でみてきたように、日本手話と日本語のバイリンガル家庭では、親が「ろう児 の最も理解し使用できる言語は日本手話である」と認識し、家庭の言語として位置 付けている。しかし、音声を伴わない日本手話を用いることが聴児の言語使用にど のような影響を及ぼすのかについて、必ずしも確信が持てているわけではない。 
例えば、2歳のバイリンガル聴児をもつ母親は、バイリンガル聴児が全く声を出さ ないことを心配していた。

「この子 (バイリンガル聴师) が、全然声で話をしないので、他の親とも相談して、 (1 年前に)保育園に入れることにしました。初めは聞こえるお友達にも声を出さずに、 手話で話しかけていたようで、このまま状況が変わらないと、専門の病院で見てもら わないといけないって保育園の先生とも相談して、そう思っていたんですけど、今は そこまでではなくてお友達とは声で話をしてます。」

(2013.7 筆者インタビューメモより。（）は筆者加筆）

また、別の母親は、親(バイリンガル聴児の祖母)がバイリンガル聴児のモードスイッ チをみて日本語の習得に不安を覚えたという話を語っている。

「Nがまだ小さかった帱、ある時は声で話したかと思うと、ある時は声を出さずに 手話で、とか声つけながら (手話) とか、そんな様子を見て、うちの母がこのまま で大丈夫かって心眍してました。」

（2011.5 筆者インタビューメモより。（）は筆者加筆。N は仮名。K の姉）

このように、バイリンガル聴児の言語使用を明らかにすることは、ろう児をもつ家 庭が言語方針を検討する上で、重要な検討事項の一つと考えられる。

中でも、モードスイッチは、他の音声言語同士のバイリンガル児には見られない 現象であり、これまで音声言語同士のバイリンガルを中心に行われてきたバイリンガ ル児の研究では、取り上げられることがないテーマである。

モードスイッチといったバイリンガル聴児の言語使用を研究対象とした研究は、 $\mathrm{K}$ やろう児（Kの兄）の姉にあたるバイリンガル聴児 N（1999.5 生まれ）を対象とした 平 (2008) の研究等を除き見当たらない。

そこで、本論文では、バイリンガル聴児の言語使用の実態を明らかにするべく、 バイリンガル聴児 $\mathrm{K}$ が使用するモードと言語構造との関係に焦点をおき、研究を行 うこととする。

\section{2. 手指モードにおける手指表現の言語構造}

一般的に手指モードで表現されるものは「手話」と呼ばれているが、そこには、大 きく分けて 2 つ異なる言語構造をもつものが含まれている。一つは、日本語の言語構 造をもつ手指日本語、もう一つは日本語とは異なる言語構造を有する日本手話である。

例えば、日本手話では、手指以外の表情や視線、口型等が文法的な役割を担い、 それらは非手指マーカー（NMM）と呼ばれている。そして、動詞や形容詞を示す 


\section{モードスイッチに打ける言語構造の切り替え}

手話単語に伴う口型が副詞的な役割を帯びた非手指副詞等、マウス・ジェスチャー と呼ばれる日本手話独自の口型が存在する（岡・赤堀 2011 他）。また、話者の役割 や参照枠の交替を明示するロールシフト（リファレンシャルシフト）を示す視線の変 化も NMM の一つである（岡・赤堀 2011 他）。さらに、手話の語彙を空間の任意の 位置で表出し、特別な意味を付加している（木村・市田 2014 他）。語順については、 日本手話も日本語と同様 SOV を基本語順とするが、形容詞と名詞の語順では、名詞 一形容詞といった語順が見られる（市田 1998 他）。

一方、音声日本語を話しながら、手指表現を付加したシムコムモードの場合、そ の手指表現は日本語の言語構造をもつ傾向にある（木村・市田 1996, 木村 2011 他）。

仮に、シムコムモードで話をしていた $\mathrm{K}$ が音声を消し、手指モードでの発話に切 り替えた際、その手指表現は、(1)シムコムモードの時と同じように日本語の言語構造 を保持したままの場合もあれば、(2)言語構造が切り替えられ（コードスイッチがなさ れ）、日本手話での発話となっている場合も想定される。

はたして、Kがシムコムモードから手指モードへとモードスイッチを行う場合、手 指表現の言語構造は日本語から日本手話へと切り替わる（コードスイッチ）のだろう か(表 1)。

表 1 モードスイッチとコードスイッチ

\begin{tabular}{|c|c|c|c|c|}
\hline & シムコムモード & $\rightarrow$ & 手指モード & 推測される結論 \\
\hline 音声 & 日本語 & \multirow{3}{*}{$\begin{array}{l}\text { モード } \\
\text { スイッチ } \\
\text { (音声を消す) }\end{array}$} & $\longrightarrow$ & \\
\hline \multirow[t]{2}{*}{ 手指 } & \multirow[t]{2}{*}{ 手指日本語 } & & (1)手指日本語 & コードスイッチなし \\
\hline & & & (2)日本手話 & コードスイッチあり \\
\hline
\end{tabular}

本研究は、シムコムモードと手指モードとのモードスイッチの際に、手指表現の言 語構造が切り替えられているのか（コードスイッチが起きているのか）を分析し、K の使用するモードと言語構造との関係を明らかにすることを試みるものである。

\section{4. 研究対象}

本研究で対象としたのはバイリンガル聴児 K（2007.10 生まれ、女児）である。平 日は聞こえる母親と $\mathrm{K}$ の兄であるろう児 (2002.8 生まれ) と 3 人で暮らしている ${ }^{3}$ 。 ろう児は、ろう学校に通学しており、Kは日中、母親と一緒に過ごしている。週に 1 度、子どもサークルに通い、聞こえる子ども達と過ごす時間ももっている。つまり、 ほとんどの時間は音声日本語の環境で生活しており、日本手話を用いるのはろう児 
が学校から帰宅し、ともに過ごしている間がメインとなる。母親はろう児が 3 歳にな る頃から日本手話を習い始め、手話学習歴は 5 年程度である。また、筆者 (以下、P) は、 手話通訳士で手話学習歴は 15 年程度あり、ろう者のいる場面では声を使用せず日本 手話で話すことが多く、ろう児がいない時には、 $\mathrm{K}$ や母親とは音声で話をしている。 対象家庭には、 2 年程前から訪問しており、 $\mathrm{K}$ やろう児も $\mathrm{P}$ が聞こえていることを承 知している。図 1 は、2010 年 1 月〜 2012 年 3 月の間に計 18 回訪問し収録した食事 場面での K 及び母親、万う児、 $\mathrm{P}$ のモードの使用状況である。インターバル記録法 を用い、収録データを 10 秒ごとに区切り、その区間にみられた発話について誰から 誰にどのようなモードが用いられたのかを記録、その出現頻度（度数）をグラフ化し ている。

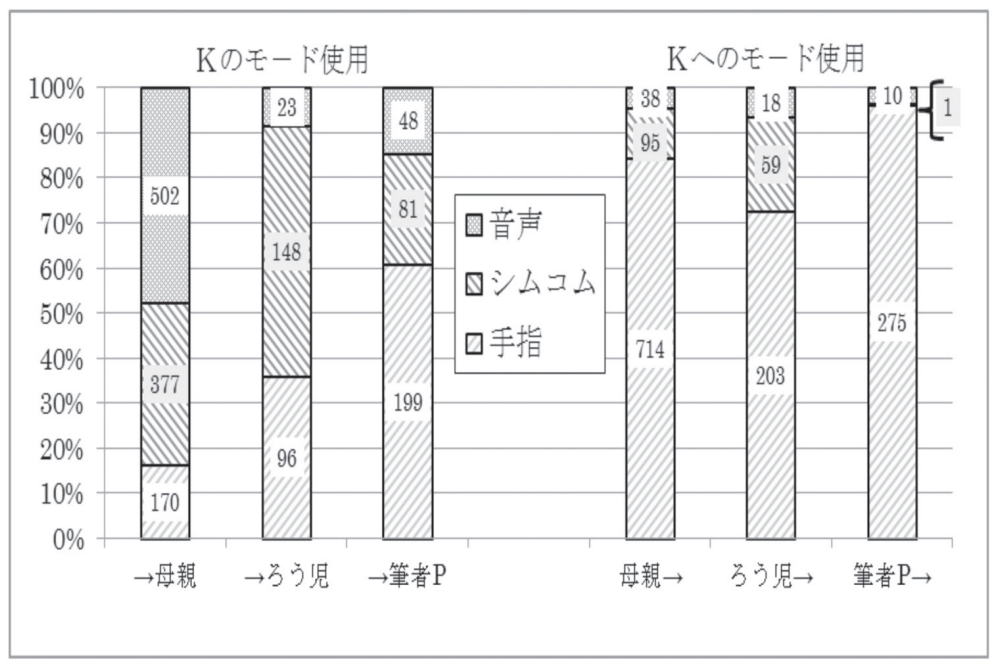

図 1 モードの使用頻度

このように、 $\mathrm{K}$ は母親、ろう览、 $\mathrm{P}$ から手指モードで話しかけられることが多いが、 $\mathrm{K}$ からの発話では、モードの使用が相手によって異なることが分かる。Pに対しては、 発話の約 60\%が手指モードとなっているのに対し、母親には約 15\%程度に留まってい る。また、 $\mathrm{K}$ はろう児に対してよりも聴者である $\mathrm{P} に$ 対してのほうが手指モードでの 発話の割合が多い。これについては、(1)万う児に対してシムコムモードを使用するこ とにより周囲にいる母親や P にも話の内容が周知されやすいという audience design (Clark 1992) が動いていたり、(2) P に比べシムコムモードでの話しかけが多く、手指 モードでの話しかけが少ないろう児に対し、Kの発話が、相手が聞こえるか否かよりも、 どのモードを使用しているのかに影響されているなど様々な要因が考えられる 4 。 
また、参与観察からろう児がいない場面では、 $\mathrm{K}$ と母親との会話は、音声日本語 でのやりとりがほとんどであるが、時折お互いがシムコムモードで話すことも観察さ れた。また、稀ではあるが音声を伴わず手指モードで会話をする場面も見られた。

\section{5. 分析 1 手指モードの言語構造}

Kのモードスイッチにおける言語構造の切り替えをみていく前に、分析 1 として、 $\mathrm{K}$ の手指モードの言語構造を動詞や形容詞に共起する口型を指標として、分析を試みる。

\section{1. 分析データ}

分析 1 で対象となるデー夕は、定点カメラにより撮影されたKの食事場面での発 話データである。学齢等の変化により言語使用に変化が生じる可能性もあるため、 2010 年 2 月〜 7 月の計 6 回のデータに加え、2012 年 1 月〜 3 月の 4 回のデータも分 析対象とした。データには、筆者 P が家庭を訪問し食事を共にしている場面と、K、 母親、ろう巟の 3 人のみの場面とを含んでいる（表 2$) 。$

表 2 分析 1 対象データ

\begin{tabular}{|c|c|c|}
\hline \multirow{2}{*}{ 参加者 } & \multicolumn{2}{|c|}{ データ収録日（)はデータの時間 } \\
\hline & $\begin{array}{l}\text { 2010. 2〜7 } \\
(K: 2 \text { 歳4ヶ月〜2歳9ヶ月) }\end{array}$ & $\begin{array}{l}\text { 2012. 1〜3 } \\
\text { (K:4歳3ヶ月～4歳5ヶ月) }\end{array}$ \\
\hline $\begin{array}{l}\text { 聴児K、母親 } \\
\text { ろう児、筆者P }\end{array}$ & 3. $9\left(24^{\prime} 20\right) 7.12\left(33^{\prime} 30\right)$ & $\begin{array}{l}\text { 1. } 31\left(31^{\prime} 40\right) 2.13\left(13^{\prime} 30\right) \\
\text { 2. } 21\left(21^{\prime} 30\right)\end{array}$ \\
\hline $\begin{array}{l}\text { 聴児K、母親 } \\
\text { ろう児 }\end{array}$ & $\begin{array}{ll}\text { 2. } 15\left(26^{\prime} 20\right) & 5.18\left(18^{\prime} 10\right) \\
\text { 6. } 23\left(15^{\prime} 40\right) & 7.8\left(16^{\prime} 00\right)\end{array}$ & 3. $12\left(28^{\prime} 20\right)$ \\
\hline
\end{tabular}

\section{2. 分析方法}

日本手話と手指日本語とでは、ほとんどの手話単語が共通しており、語彙から両者 を区別する事は難しい。日本語と日本手話の基本語順もSOV と共通している（米川 1984, 岡・赤堀 2011 他)。また、プロソデイーの側面から日本手話と手指日本語とを区 別する研究（原・黒坂 2011）なども存在するが、対象が幼児の場合、日本手話の言語 習得の段階で生じるエラーなのか、手指日本語を用いているのかの区別は困難である。

シムコムモードの場合、日本語を話しながら手指表現も行うため、必然的に動詞 や形容詞を示す手指表現に伴う口型は日本語口型（マウジング）となる。

一方、日本手話では、日本語の言い回しをそのまま表現するような特殊な場合を 除いて、動詞や形容詞に日本語口型は伴わない。日本手話独特の口型はマウスジェ 
スチャーと呼ばれている（岡・赤堀 2011）。マウスジェスチャーには、「アイウエオ」 といった「ア系」や「パピプペポ」といった「パ系」等が存在する（吉田 2005）。中 でも、動詞・形容詞を表す手話表現に副詞的情報を付加する口型は非手指副詞と呼 ばれ、手話言語の特徴とされている。例えば、唇を軽くとがらせる「ウ」の口型は「問 題なく、普通に」、口を軽く開いて舌を覗かせる「エ」の口型は「考えもなしに、気 づかずに」、をを真一文字に結んだ口型（以下「 $\mathrm{mm} 」$ 示すと）は、「一生懸命に、しっ かりと」という意味を持つ（市田 2005b, 岡・赤堀 2011 他）。また、「パ」は「完了」 から「不可逆性」を、「ポ」は「出現」から「成就」を意味するなど、「パ系」は出 来事の変化や状態のあり方を表す（木村・市田 2014）。さらに、日本手話に伴う口型 として、ロールシフト（リファレンシャルシフト）による動作者の行為の直接引用に よる口型もみられる。このように、日本手話の動詞や形容詞には、基本的に日本語の 口型は伴わない。そして、副詞等の意味の付加がないニュートラルな表現の場合に は「ア」の口型を伴う。つまり、手指モードでは、手指表現に日本語口型の伴うもの( ウジング）と日本語口型が伴わない日本手話口型もの（マウスジェスチャー）との両 者が存在すると考えられる。

日本語の構造の場合…動詞や形容詞を示す日本語の口型を伴う。 日本手話の構造の場合 ..マウウスジェスチャーと呼ばれる独自の口型。

非手指副詞等の「ア系」「パ系」「 $\mathrm{mm} 」$ の口型。

例えば、表 3 は、バイリンガル聴児 N の発話を示したものである（平 2008）。こ の中で、 $\mathrm{N}$ はよそう」という手指表現の際に音声が消えている（表 $3: \square ） 。$

表 3 バイリンガル聴児の発話例（平（2008）をもとに作成）

データ収録日：2006 年 1 月 24 日（N：6 歳 8 ケ月）

\begin{tabular}{|c|c|c|c|c|c|}
\hline $\begin{array}{l}\text { 発話 } \\
\text { 番号 }\end{array}$ & $\begin{array}{l}\text { 話者 } \\
\rightarrow \text { 相手 }\end{array}$ & $\begin{array}{l}\text { モダリ } \\
\text { ティー }\end{array}$ & \multicolumn{3}{|l|}{ 発話内容 } \\
\hline 1 & $\underset{\mathrm{N}}{\mathrm{N}}$ & $\begin{array}{l}\text { 音声 } \\
\text { 手指 }\end{array}$ & $\begin{array}{l}\text { ある } \\
\text { ある 指差し一血。 }\end{array}$ & & \\
\hline 2 & $\mathrm{M}_{\rightarrow \mathrm{D}}$ & $\begin{array}{l}\text { 音声 } \\
\text { 手指 }\end{array}$ & ある、ある。指差しー皿 なくなる 次 探 & & \\
\hline 3 & $\stackrel{\mathrm{N}}{\rightarrow \mathrm{D}}$ & $\begin{array}{l}\text { 音声 } \\
\text { 手指 }\end{array}$ & $\begin{array}{c}\text { ペーも食ベーパ から } \\
\text { ねえ、ペー 食ベーた } \text { から } \\
\text { ね指差しーおでん }\end{array}$ & よそう & $\begin{array}{c}\text { してるからな。 } \\
\text { する。 }\end{array}$ \\
\hline
\end{tabular}

$\mathrm{N}$ はバイリンガル聴児（姉 6 歳）、D はろう児 (弟 3 歳)、 $\mathrm{M}$ は聴親。口は筆者加筆。

*「指さし - ○○」は○○を指差していることを表し「-た」は、手話語彙／終わり／を用いた過去形を表す。 1 つの発話には、音声での表現（上段）と手指での表現（下段）とを記載し、上下段が重なっている場合は、 シムコムモードを表している。また、発話番号 2 にあるぺーは筆者 P のあだ名である。(以下、同様) ${ }^{5}$ 
この手指表現の箇所の映像データを確認したところ、日本語口型「よそう」が共 起せず、「しっかりと」という副詞的な意味をもつ「 $\mathrm{mm}$ 型がみられる。

分析 1 では、Kの手指モードにおける動詞・形容詞に焦点を当て口型の特徵をみ ていく。その際、明らかに動詞・形容詞と判断できるものに共起する口型を対象とし、 データにてロ型が確認できないものや、物まねや手遊びなど明らかに身振りに共起 しているものは分析の対象から除外した。なお、一つの談話内で繰り返し表出され る動詞や形容詞は 1 つとして計上した。

\section{3. 分析 1 結果と考察}

結果、データにおいて K は音声モードやシムコムモードで発話することも多く、 $\mathrm{K}$ の手指モードにおける動詞・形容詞は延べ 40 単語であった。そのうち、日本語口型 が伴っていたのは/もらう/の 1 単語であった。また、日本語口型を伴わない 39 単 語のうち、「プー」というオノマトペとも考えられる口型を伴う/ふくらます/を除き、 38 単語はマウスジェスチャーを伴うものであった（表 4)。この事から手指モードで は日本語の言語構造は現れにくいと考えられる ${ }^{6}$ 。

表 4 分析 1 結果 手指モードの動詞・形容詞と日本語口型の有無

*/は手話単語、（）は共起した口型のタイプを示す。

\begin{tabular}{|c|c|c|}
\hline データ & 抽出された動詞・形容詞(手指モード) & 日本語口型 \\
\hline $\begin{array}{r}2010 . \\
2.15\end{array}$ & $\begin{array}{l}/ \text { 合格する(ポ)//寝る(ア)//おいしい(ア)//料理する(ア)/ } \\
\text { /おいしい(ア)//思う(ア)//ほしい(ア)//運転する }(\mathrm{mm}) / \\
\text { /寝る(ア)//難しい(ア)/ }\end{array}$ & 0 \\
\hline 3.9 & $\begin{array}{l}\text { /食べる(ア)//混ぜる(ア)//思う(ア)//おいしい(ア)/ } \\
\text { /閉まる(ア)/ }\end{array}$ & 0 \\
\hline 5.18 & /聞こえる(ア)//もらう(モラッ)/ & $1(/$ もらう/) \\
\hline 6.23 & /撮影する(ア)//吐く(オ工)//分かる(ア)//寝る(ア)/ & 0 \\
\hline 7.8 & /寝る(ア)//ある(ア)//行く(ア)/ & 0 \\
\hline 7.12 & /寝る(ア)/ & 0 \\
\hline $\begin{array}{r}2012 . \\
1.31 \\
\end{array}$ & /食べる(ア)//分かる(ア)//食べる(ア)//見る(ア)/ & 0 \\
\hline 2.13 & /分かる(ア)//分からない(ア)//借りる(ア）//食べる(ア)/ & 0 \\
\hline 2.12 & なし & 0 \\
\hline 3.12 & $\begin{array}{l}/ \text { 言う (ア)//跳ねる(ア)//うまい(ア)//跳ねる(ア)/ } \\
/ \text { おいしい(ア)//首絞める(ア)//ふくらます }\end{array}$ & 0 \\
\hline 計 & 延べ 40 単語 & 1 \\
\hline
\end{tabular}

/ /は手話単語の日本語ラベルを示す。 
手指モードにおける手話単語／もらう／に日本語口型がついた事例を、以下表5に示す。 発話内容は、 $\mathrm{K}$ が日中に遊びに行って、「パチパチ（腕を突くおもちゃだろうか?） を、○○ちゃんは、もらって、Kはアンパンマンをもらった」という話である。この 談話は、他の談話とは異なるスタイルを示している。 K が、「ママ」と呼びかけ、「パ チパチ」と発話したところで、母親が「○○ちゃんがそれを」と発話、それに続い てKがすかさず「もらった」と文末を引き継いでいる。そして、Kがその発話権の まま「Kはアンパンマン (をもらった)」と話している。

表 5 手指モード/もらう - た/に日本語口型「もらった」が共起した事例 データ収録日：2010 年 5 月 18 日（K：2 歳 7 ケ月）

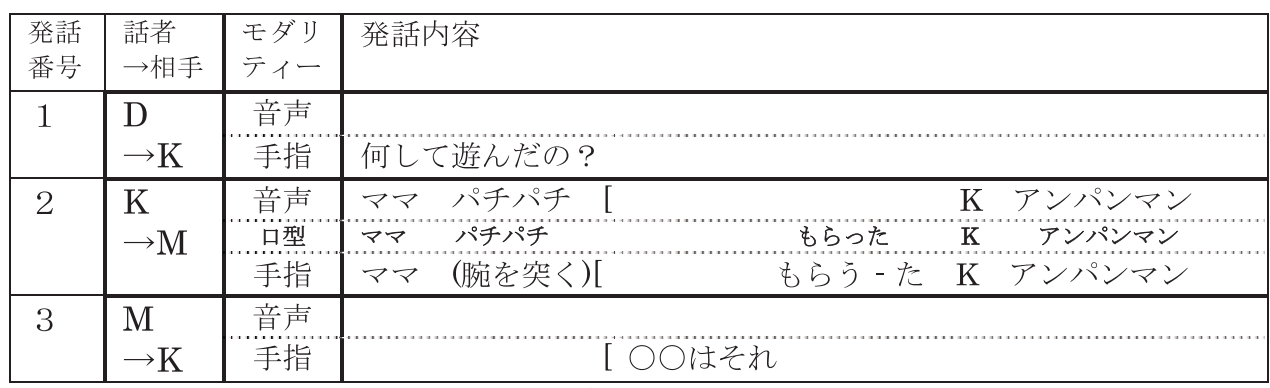

*手話の過去形では、日本語のような動詞の変化は見られず、動詞に過去を表す単語が付随する。 そのため手指での表現では日本語ラベル/らう-た/と表記しているが日本語口型は「もらった」と なっていた。なお、○○及び $\mathrm{K}$ は仮名。

これは先取り完了と呼ばれるターンテイキングの現象である（串田 2006）。串田 （2006）は、先取り完了の基本的特徴として Lerner（2004）が挙げた以下の 4 つの 特徵を紹介している。

(1) 進行中のターンの統語的形式を踏襲し組み立てられる。

(2) そこまで産出されたターンに連続することを示すべく、すなわち、それが新しい ターンの始まりでない事が認識可能なようにデザインされ配置される。

（3）進行中のターンを完了させるべく、しかも最初の完了可能点で完了させるべく 行われる。

（4）ターン開始者によって自分が開始したターンの可能な完了の一例として扱われ別 の独立したターンとは聞かれない。（串田 2006, pp.160-161）

特徵の一つに「進行中のターンの統語形式を踏襲」とあるが、 $\mathrm{K} の$ 場合には、シ ムコム（日本語の言語構造）で話していたところに、母親が手指モードで話し始め、 $\mathrm{K}$ は日本語の言語構造のまま、手指モードを踏襲したと考えられる。先取り完了に より直前の話者のスタイルを踏襲するという特殊な状況の中で、手指モードに日本 
語口型が共起したものが見られたと推測される。

\section{6. 分析 2 モードスイッチと言語構造の切り替え}

分析 1 では、手指モードにおける動詞や形容詞に伴う口型を指標とし、語彙レべ ルでの言語構造の相違について分析をすすめた。そして、手指モードでは、シムコ ムモードと異なり日本語の言語構造が現れにくいことが示唆された。

しかし、分析 1 では、コンテクストの異なる広範囲の自由会話のデータを分析対 象としているため、モードスイッチが話題等の変化といった要因による可能性もある。 はたして、話題等のコンテクストが一定の中、モードが切り替えられるモードスイッ チの場合にも、言語構造が切り替えられているのであろうか。分析 2 では、カードゲー 厶場面という特定の場面における Kの手指表現の言語構造を統語論的枠組みからみ ていく事とする。

\section{1. 分析データ}

分析 2 で、対象としたデータは、 $\mathrm{K}$ が $\mathrm{P}$ とスリーヒントゲーム（メーカー：学研） をしている場面である。スリーヒントゲームは、カル夕遊びの一種で、読み手が読み 札にある 3 つヒントを言い（出題し）、それに合った絵札を取り合うというゲーム である。いつもは母親が声を出さず日本手話で札を読み、ろう児や $\mathrm{K} 、$ 時には $\mathrm{P} も$ 含めカードを取り合って遊んでいる。

2012 年 2 月 21 日 K (4 歳 4 ケ月) と $\mathrm{P}$ とが 2 人で K の家で留守番をすることになり、 その間にゲームを始めた。データの流れは以下(1)〜(3)のとおりである。

(1)当初は、Pが読み手 (出題者) となり日本手話でヒントを出していたが、途中で $\mathrm{K}$ が読み手をしたいと希望し、交替した。

(2)しかし、Kはまだ字がスムーズに読めず、結局、広げてある絵札を見て、自分で ヒントを出すこととした。ヒントを出す際、K はシムコムモードで進めていた。

(3)その後、Pが声を出さないで出題することを提案した。シムコムモードだと $\mathrm{K}$ が 出題している途中でも $\mathrm{P}$ は聞きながら探し始めることができ、 K が不利になるか らである。 $\mathrm{P}$ はこの理由を $\mathrm{K} に$ 話し、 $\mathrm{K}$ は声を消して手指モードで出題を始める。 しかし、結局、手指モードだけではなく、声を加えたシムコムモードや手指に（無 意識であろうが）漏れるような小声が伴ったもの（「手指＋小声」モードと表記す る）で出題を行っている。

このデータでは、K が日本語の文章ではなく、絵札をみて自分でヒントを考え発話 をしている。つまり、読み札に書かれている日本語を基に手話を行っているわけでは なく、発話が日本語に影響される可能性は低いと考えられる。また、ヒントを出すと いう一定のコンテクストの中で発話が行われ、モードスイッチの要因が話題等のコン テクストの変化による可能性が低いデータと言える。さらに、声を消す目的が、ゲー 
ムを楽しむためであり、「日本手話に切り替えなければならない」という指示に基づ くものではない。これらの事からモードの切り替えと言語構造の切り替えとの関係を 分析するのには適した状況と言える。以下に、今回分析対象としたデータにおける $\mathrm{K}$ と $\mathrm{P}$ との発話例を一部紹介する（表 6)。

\section{表 6 分析 2 発話例}

データ収録日：2012 年 2 月 21 日（K：4 歳 4 ケ月）

\begin{tabular}{|c|c|c|c|}
\hline $\begin{array}{l}\text { 発話 } \\
\text { 㽬 }\end{array}$ & 話者 & モダリティー & 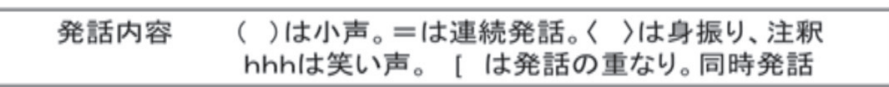 \\
\hline \multirow[t]{2}{*}{1} & \multirow[t]{2}{*}{$\mathrm{K}$} & 音声 & 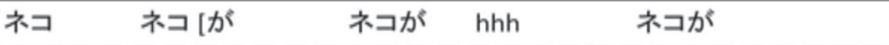 \\
\hline & & 手指 & ネコ \\
\hline \multirow[t]{2}{*}{2} & \multirow[t]{2}{*}{$\mathrm{P}$} & 音声 & [1回声なしでやってみてパ、、゚〜が当てるわ \\
\hline & & 手指 & \\
\hline \multirow[t]{2}{*}{3} & \multirow[t]{2}{*}{$\mathrm{P}$} & 音声 & これ。ネコって分かるもん。声が聞こえたから。 \\
\hline & & 手指 & \\
\hline \multirow[t]{2}{*}{4} & \multirow[t]{2}{*}{ K } & 音声 & ペンギン \\
\hline & & 手指 & ペンギン ペンギン、ブランコ 青い、服 赤い 服、青い帽子= \\
\hline \multirow[t]{2}{*}{5} & \multirow[t]{2}{*}{$\mathrm{K}$} & 音声 & =(ブランコが 青です) \\
\hline & & 手指 & =ブラシニー青いーーー \\
\hline \multirow[t]{2}{*}{6} & \multirow[t]{2}{*}{$\mathrm{P}$} & 音声 & はい。ペンギン \\
\hline & & 手指 & \\
\hline \multirow[t]{2}{*}{7} & \multirow[t]{2}{*}{$\mathrm{K}$} & 音声 & （おサルがスケートをして、＜wide>スケートが青です） \\
\hline & & 手指 & ーサル ステート する 青い、ススケート 青いー \\
\hline \multirow[t]{2}{*}{8} & \multirow[t]{2}{*}{ K } & 音声 & $\begin{array}{l}\text { 服、(服が、帽子が、帽子が 赤 です) } \\
\end{array}$ \\
\hline & & 手指 & 〈カード指差し〉服、、服 帽子ーー帽子赤いです \\
\hline
\end{tabular}

\section{2. 分析方法}

スリーヒントゲームの出題では、物とその色に関する発話が多く見られる。分析 2 では、形容詞と名詞の語順に焦点を当て、分析を試みた。形容詞と名詞の語順につ いて、日本語や手指日本語が「形容詞一名詞」であるのと異なり、日本手話の場合 には「名詞一形容詞」という語順で表れる場合があることが手話研究者の間で指摘 されている（佐藤 1973, 米川 1984, 市田 1998 他)。市田（1998）は、その理由を以 下のような $2 つ の$ 例文を挙げ統語的な観点から説明している。なお、以下の例文の [ ] は非手指マーカーによる発話の区切りを示している。

\section{(1) [田中][おいしい 弁当 買う] \\ (2) [田中][弁当 おいしい][買う]（市田 1998）}




\section{モードスイッチに打ける言語構造の切り替え}

両者とも「田中さんがおいしい弁当を買う」という同じ事象を表したものである。 市田（1998）によると日本手話の場合は(2)のように [弁当 おいしい（弁当がおいし い） ] といった手話文を関係節として語順を変えずに挿入することができ、そのため (1)と(2)のよな語順の違いが生じるという。この名詞と形容詞の語順は、日本語と日 本手話とで異なる特徴の一つと言える。

そこで、分析 2 では、手指日本語と日本手話との言語構造を区別するのに、名詞 と形容詞の語順という統語論的枠組みを用いた。Kが、シムコムモードから手指モー ドへとモードスイッチを行う際、形容詞と名詞の語順が、「形容詞－名詞」から「名 詞一形容詞」へと切り替わっているのであれば、日本語から日本手話へと言語構造 の切り替え（コードスイッチ）が行われていると考えられる。

\section{3. 分析 2 結果と考察}

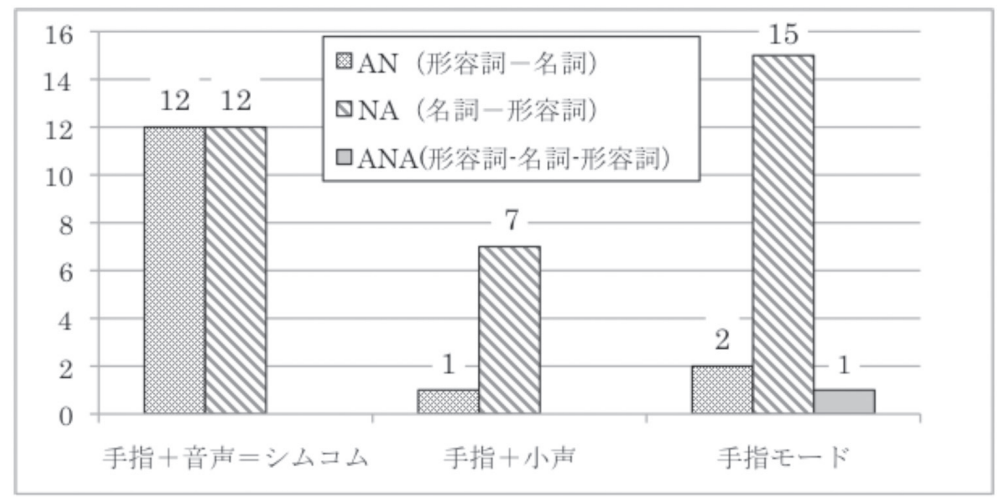

図2 分析 2 結果 モードと形容詞と名詞の語順

データの中で色を表す形容詞と名詞の組み合わせは全部で 50 組見られた。この 50 組には、表 6 の発話番号 7 でみられる [青い、スケート 青い] の初めの「青い」 と「スケート」のような、言いよどみ等で形容詞と名詞が単に連続してはいるが文 法的関係が見られないものは、含まれていない。50 組のうちシムコムモードは 24 組、 手指モードが 18 組であった。さらに「手指十小声」も8 組みられた。また、「形容 詞 - 名詞 - 形容詞」という組み合わせも 1 例見られた（図 2) 7 。

「形容詞一名詞」の語順は 15 組見られ、シムコムモードでは 12 組であるのに比し、 「手指十小声」モードでは 1 組、手指モードでは 2 組である。また、「形容詞一名詞」 の語順がシムコムモードの場合に表れる頻度と「名詞－形容詞」の語順がシムコム モードの場合に表れる頻度を $\chi$ 二乗検定で比較したところ、5\%水準 $(\mathrm{p}=0.0325<5 \%)$ 
で有意差が見られ、「形容詞一名詞」の語順はシムコムモードで表れやすいと言える。

一方、「名詞一形容詞」の語順は、34 組見られ、シムコムモードでは 12 組で「手 指十小声」モードでは 7 組、手指モードでは 15 組であった。「手指十小声」モード や手指モードでは、「名詞－形容詞」の語順が「名詞－形容詞」に比し、多く表れて いる。このことから、日本語の構造はシムコムモードで表れやすく、日本手話の構造 は手指モードで表れやすいと言える。

しかしながら、日本手話の構造（「名詞一形容詞」）は、「手指＋小声」モードでも 出現しやすく、シムコムモードにおいても「形容詞一名詞」の組み合わせと同数みら れる。

音声言語のバイリンガルに関する研究を行っている Grosjean（2001）は、バイリ ンガル話者の「言語モード」について述べている。Grosjean（2001）によると、バイ リンガル話者は、モノリンガルモードとバイリンガルモードを有しており、バイリン ガルモードにある時は 2 つ言語システムの両方が働きやすい状態で、コードスイッ チをしやすいという。K の場合、手指モードでは、日本手話のモノリンガルモードに なる傾向にある一方、音声を伴うシムコムモードでは、日本手話と日本語のバイリン ガルモードとなる傾向にあると考えられる。

\section{7. 結論}

本研究では、バイリンガル聴児 $K$ の発話データを対象とした 2 つの分析から、モー ドと言語構造の関係についてみてきた。

分析 1 では、動詞、形容詞に共起する口型を指標とし、手指モードでは日本語の 口型は見られず、日本手話の口型が見られる傾向にあることが示唆された。

さらに、分析 2 では、カードゲーム場面での $\mathrm{K}$ の発話に注目し、名詞と形容詞の 語順の分析を試みた。結果、日本語の構造（形容詞－名詞）はシムコムモードで表 れやすく、手指モードでは日本手話の構造（名詞一形容詞）が表れやすいことが明 らかとなった。また、手指モードに音声を加え、シムコムモードへモードスイッチを することにより、K $\mathrm{K}$ は、それまで日本手話のモノリンガルモードであったものが日本 手話と日本語のバイリンガルモードに切り替わり、コードスイッチを誘発しやすい状 態になると示唆される。

手指モードとシムコムモードとの間でのモードスイッチは、単にモードが切り替え られるというだけではなく、日本手話と日本語との言語構造の切り替え（コードスイッ チ）を誘発すると考えられる。

\section{8. さいごに}

本研究は $\mathrm{K}$ の言語使用についてデータに基づき分析したケーススタディーである。 $\mathrm{K}$ のモードスイッチと言語の構造について明らかにしたものの、1軒の家庭の 1 人の 


\section{モードスイッチにおける言語構造の切り替え}

バイリンガル聴児を対象としたに過ぎず、本論文で示唆されたものが、他のバイリ ンガル聴児でも同様であるのかといった検証は今後のバイリンガル聴児の言語使用 に関する研究の進展に委ねざるを得ない。

日本手話と日本語のバイリンガル聴児の研究は、始まったばかりである。今後、 バイリンガル聴児の研究がさらに発展し、その研究成果が、ろう児をもつ家庭の言 語方針の検討やその他様々な場面で活用されることを願ってやまない。

\section{謝辞}

本研究にご協力いただきましたご家庭の皆様、その他多くの方々に感謝申し上げ ます。ありがとうございました。

\section{注}

コードスイッチには、片方の言語構造をもつ発話にもう片方の言語の語彙が挿 入されるという挿入型のコードスイッチも存在する（Myers-Scotton 1997 他）。しか し、日本手話と手指日本語とでは、使用される手話単語が共通していることが多く、 語彙レベルで判断するのは難しく、本研究では、後で述べる手話語彙に共起する口 型や名詞と形容詞の語順といった言語構造で比較分析を行う。

2 山本 (1991) は、バイリンガルの定義について「2つの言語を母語話者のように コントロールできること」という狭義の定義から「ある言語の話してがもう一つの言 語で完結し、かつ有意味である発話ができる」という広義の定義まで、研究者の様々 な定義を紹介した上で、それらの中間的な定義としてバイリンガル話者を「2つの言 語を使用する能力をもつ者」としている。本稿は、山本（1991）の定義に従うものと する。

3 研究対象家庭の実家がある某県のろう学校では、手話での教育環境が整ってい ない。そのために、母親は手話での教育環境が整っている他県の公立ろう学校にろ う児を通わせるため父や長女と離れろう児や $\mathrm{K}$ と引っ越さざるを得なかった。ろう 学校に手話での教育の選択肢がないことが対象家庭の離散を招いている。

K が、相手のモード使用に応じてモード選択をしているという傾向は、データ 収集開始直後の時期（2010.1～2010.7）に顕著にみられた。しかし、母親がその後 $\mathrm{K}$ に対し、手指モードの使用の割合を増加させても $\mathrm{K}$ は母親に対し手指モード使用 の割合を増加させることはなかった。この要因に対する分析は今後の研究に委ねる こととする。

食べぱの「ぱ」は、日本手話における完了を示すパ系の口型 (マウスジェスチャー) に音声が付いたものである。

6 ほとんどの口型が「ア」型であった。この要因には、 $\mathrm{K}$ が非手指副詞等の習得 過程にある可能性も考えられる。 
7 「名詞一形容詞」と「形容詞－名詞」という 2 つの言語構造が存在する「服一赤 いー服」という手指モードの表現（表 6 発話番号 4 参照）が 1 例見られた。このよ うな異なる言語構造が両立する文は、音声言語のバイリンガルの研究では、言語構 造（語順）の異なる 2 つ言語を有するバイリンガルに見られるコードスイッチの 特徵とされ、その鏡像的構造から「画開きカバン構文」と呼ばれている（Nishimura 1997, Namba 2012 他）。1例であるが、音声言語のバイリンガル同様の現象をバイ リンガル聴児も見せている事が示唆される。

\section{参考文献}

我妻敏博 (2008)「聾学校における手話使用の調査」『聾学校におけるコミュニケーショ ン手段に関する研究ー手話を用いた指導法と教材の検討を中心に一』国立特別 支援教育総合研究所, pp.139-147.

千葉県聴覚障害者協会活動運営委員会 (2011)『全国のろう学校, 情報提供施設, 聴覚 障害者協会』千葉県聴覚障害者協会活動運営委員会.

Clark, H. H. (1992) Arenas of language use.Univ of Chicago Press.

Clyne, M. G. (2003). Dynamics of language contact. Cambridge: Cambridge University Press.

Comeau, L., Genesee, F. and Lapaquette, L. (2003). The Modeling

Hypothesis and Child Bilingual Codemixing. The International Journal of Bilingualism, 7(2), 113-126.

Elena Nicoladis. (2002) What's the difference between 'toilet paper' and 'paper toilet'?

French-English bilingual Children's cross nouns. Journal of Child Language Vol.29. pp.843-863. Cambridge Press.

Emmorey, K., Borinstein, H.B., Thompson, R. (2005). Bimodal bilingualism: Codeblending between spoken English and American Sign Language. In J. Cohen, K. McAlister, K. Rolstad, \& J. MacSwan (Eds), Proceedings of the 4th International Symposium on Bilingualism. Somerville, MA: Cascadilla Press.

Grosjean, F. (2001). Bilingual language mode. In J. Nicol (Ed), One mind, two language:

Bilingual processing. pp.1-22. Oxford: Blackwell Publishing.

Gumperz, J. J. (1982). Discourse strategies. Cambrige, UK: Cambrige Universuty Press. 原大介, 黒坂美智代 (2011)「いわゆる「中間手話」の中間性の検証〜語表出の特徴

について〜」第 37 回日本手話学会大会予稿集 , pp.20-21.

市田泰弘 (1996)「誤解される言語 - 手話」『現代思想』第 24 巻第 5 号, 青土社, pp.233-247.

市田泰弘 (1998)「日本手話の名詞句内の語順について」『日本手話学会第 24 回大会 予稿集』pp.50-53. 
市田泰弘 (2005a)「手話の言語学 $(1) \sim(12) 」 『$ 月刊言語』第 34 巻第 1 号 12 号, 大修館書店。*連載記事

市田泰弘 (2005b)「手話の言語学 (8) 頭の位置と口型 - 日本手話の文法 (4)「知覚・思

考動詞と非手指副詞」」『月刊言語』第 34 巻第 8 号, pp.92-99, 大修館書店.

加藤美保子 (2007) 「聴覚障害児の母語教育」『異文化間教育 26』アカデミア出版会,

pp.40-53.

木村晴美, 市田泰弘 (1996)「ろう文化宣言」『現代思想』pp.8-17, 青土社 .

木村晴美, 市田泰弘 (2014)『はじめての手話』生活書院 .

木村晴美 (2011)『日本手話と日本語対応手話 ( 手指日本語)』生活書院.

串田秀也 (2006)『相互行為秩序と会話分析 - 「話し手」と「共一成員性」をめぐる

参加の組織化』世界思想社 .

ロバート・E・ジョンソン，スコット・K・リデル\&キャロル・ $\mathrm{J} \cdot$ アーティィング著,

神田和幸・森壮也訳, 神田和幸監修「学力の遅れをなくすために一ろう教育にお

ける学力獲得のための基本原則」日本手話学術研究会.

LI, W. (1998) The 'Why' and 'How' Questions in the Analysis of Conversational

Code-Switching. In Auer, P. Code-Switching in Conversation: Language,

Interaction and Identity. London and New York: Routledge.

Lucas, C. \& Valli, C. (1992). Language Contact in the American Deaf Community.

New York: Academic Press, Inc.

Muysken, P. (2000). Bilingual speech: A typology of code-mixing. Cambridge, UK ;

New York: Cambridge University Press.

Myers-Scotton, C. (1997) Duelling language: Gramatical structure in codeswitching $\left(2^{\text {nd }}\right.$ ed). Oxford: Clarendon Press.

中村成子 (2003)「母親法の指導を受けて」全国ろう児をもつ親の会『ぼくたちの言葉

を奪わないで〜ろう児の人権宣言〜』明石書店, pp.76-83.

Namba, K. (2012). English-Japanese Code-switching and Formulaic Language: A

Structural Approachto Bilingual Children's Interactions. Saarbrücken:

Lamgert Academic Publishing.

Nishimura, M. (1997). Japanese/English code-switching: Syntax and pragmatics.

New York: P. Lang.

岡典栄, 赤堀仁美 (2011)『日本手話のしくみ』大修館書店 .

冷水生来 (1981)「手話を併用するろう児と口話のみのろう幼児の母子交渉の語用論

的分析」特殊教育学研究 19 (1) 日本特殊教育学会, pp.1-10.

佐藤則之 (1973)「手話について」『言語生活』第 258 号 (1973 年 3 月号), 筑摩書房.

Shimamura Koji, LynShanTieu (2013) When You Can and Can't See Double:

Revisiting Focus Doubling in ASL Current Issue: Volume 19, Issue 2 (2013) 
Selected Papers from NWAV 41University of Pennsylvania Working Papers in Linguistics.

都築繁幸 (1997)『聴覚障害教育コミュニケーション論争』御茶の水書房 .

山本雅代 (1991)『バイリンガルーその実像と問題点-』大修館書店 .

山本雅代 (編著) 井狩幸男, 田浦秀幸, 難波和彦 (2014)『バイリンガリズム入門』 大修館書店。

吉田麻利江 (2005)「ろう児のマウスジェスチャーの獲得について」国立身体障害者リ

ハビリテーションセンター学院手話通訳学科第 14 期卒業研究発表会配布資料.

米川明彦 (1984)『手話言語の記述的研究』明治書院.

米川明彦 (2002)『手話ということば』PHP 研究所 .

全国乃う児をもつ親の会 ( 編) (2004)『ろう教育と言語権一ろう児の人権救済申立の 全容』, pp.9-46, 明石書店.

平英司 (2008)「日本語－日本手話バイリンガル児の発話内 W コーデイングについて」

関西学院大学言語コミュニケーション文化研究科修士論文.

- 2014 年 10 月 23 日受理、 2015 年 4 月 27 日掲載決定一 


\title{
Switching language structure during mode-switches - The case study of the bilingual hearing child K-
}

\author{
Eiji Taira \\ Kwansei Gakuin University
}

taira82@gmail.com

\begin{abstract}
This thesis is a case study of hearing child $\mathrm{K}$ with hearing parents and a deaf brother. K 's parents use Japanese and Japanese Sign Language as a language of the home. And, her parents are bringing up the deaf child by Japanese Sign Language. $\mathrm{K}$ grows up in a bilingual environment of Japanese and Japanese Sign Language. The focus in the present study is the process of mode-switching from a simultaneous mode of using voice and sign expressions together (simcom mode) to the mode of only using sign expressions (sign mode). Concretely, it analyzes whether the linguistic structure of sign expressions switches during mode-switching.

It found that the linguistic structure of the sign expressions tended to switch from Japanese to Japanese Sign Language when mode-switching from sim-com mode to sign mode. This suggests that $\mathrm{K}$ switches linguistic structure (i.e., code switches) during mode-switching.
\end{abstract}


